\title{
05(VS)-1＼cjkstart術中情報誘導下での脳神経外科手術
}

\author{
○中村 亮一 ${ }^{a}$, 村垣 善浩a,b, 丸山 隆志 ${ }^{b}$, 堀 智勝, 伊関 洋 ${ }^{a, b}$ \\ a東京女子医科大学 先端生命医科学研究所, ${ }^{b}$ 東京女子医科大学 脳神経センター脳神 \\ 経外科
}

\section{Information-guided Neurosurgery}

R. Nakamura ${ }^{\mathrm{a}}$, Y. Muragaki ${ }^{\mathrm{a}}$, T. Maruyama ${ }^{\mathrm{b}}$, T. Hori ${ }^{\mathrm{b}}$, H. Iseki ${ }^{\mathrm{a}, \mathrm{b}}$

a Institute of Advanced Biomedical Engineering and Science, Tokyo Women's Medical University, Tokyo, Japan

' Department of Neurosurgery, Neurological Institute, Tokyo Women's Medical University, Tokyo, Japan

\begin{abstract}
In glioma treatment, surgical resection is the surest. It becomes large problem that the case which must end in many cases in subtotal resection in present surgical method, though survival rate of the total removal case is significantly higher than subtotal resection. We develop and apply "Information-guided surgery" technology for glioma treatment using the intraoperative visualization technique for glioma and brain function. Our objective on application of this technology is maximization of tumor resection volume and minimization of complication risk. We developed and installed these technology; 1) Intraoperative MRI, 2) Optical navigation system, 3) Photo-dynamic diagnosis using 5ALA, 4) Multi-monitor system for integrated intraoperative information, 5) Intraoperative Examination Monitor for Awake Surgery (IEMAS) system, and 6) Surgical strategic desk. on this presentation, we introduce the state-of-the-art glioma treatment using Computer Aided Surgery system through clinical cases of applied information-guided surgery.
\end{abstract}

Key words: Computer aided surgery, Neurosurgery, glioma treatment

\section{1.はじめに}

脳腫瘍は外科手術により物理的に摘出することが最も 確実な治療法であり、全摘出症例の生存率は部分摘出 よりも有意に高いものの、現在の手術法では、多くの場合、 部分摘出に終わらざるをえない症例が多いことが大きな 問題となっている。部分摘出の場合、手術後、放射線治 療や抗がん剤による化学療法を併用しても、最も悪性で ある神経膠芽腫の平均生存期間は 1 年という悲惨なもの となる。さらにここ 10 数年の治療成績はまったく改善して おらず、ブレークスルーが待ち望まれている。

我々は脳腫瘍の最大摘出と脳機能の温存・合併症の 最小化を目的として、2000 年 3 月に導入した術中 MRI を中心とした、脳腫瘍・脳機能の術中可視化技術に基づ く情報誘導外科(Information-guided Surgery)技術の開 発および臨床応用を行ってきた。本報ではコンピュータ 外科学技術の応用により実現した、先端脳腫瘍外科の 実際について、実際の臨床応用例を用いて紹介寸る。

\section{Multimodality 情報誘導手術}

我々が運用・研究開発を行っている術中 MRI 手術室 (インテリジェント手術室)では、悪性脳腫瘍の外科的治 療を中心に治療を実施している。この治療を支援する CAS 技術を応用した手術支援装置・技術としては以下の ものなどが現在利用されている。

1) 術中 MRI

永久磁石を用いた垂直磁場方式 $0.3 T M R I$ AIRISII(日立メディコ製)を手術室内に導入した。手 術作業及び周辺機器への影響を低減するために
Pit-in System の手法開発、MRI 対応機器(手術顕微 鏡(三鷹光器製)、手術ベッド(瑞穂医科工業製)の導 入を行っている。また術中撮像専用の RF 受信コイル システム(Head Holder Coil)を開発した。撮像プロトコ ルは T1/T2FSE、FLAIR が中心だが、プロトコル・コイ ルの研究開発により、拡散強調画像も取得でき、白室 神経線維の描出が可能である。

2) 光学式ナビゲーションシステム

独自開発した光学式ナビゲーションシステム(東芝・ インフォコムとの共同開発)により、術中 MRI により取 得した正確な腫瘍及び白室神経束の位置形状情報 を元にしたナビゲーション手術を行っている。

3） 5ALA による術中蛍光診断

迅速病理診断に加え、5-アミノレブリン酸(5ALA)の 術前経口投与・レーザ励起により発生する腫瘍細胞 からの蛍光をもとに、残像腫瘍の確認及び腫瘍性状 診断の可能性について臨床研究を行っている。

4) 術中情報統合提示システム

手術室内に設置されたマルチカメラ映像および $\mathrm{MRI}$ ・手術顕微鏡・ナビゲーションシステム画面を統合 し、手術室内に設置されたモニタ上に提示することで 手術室内スタッフの情報共有を支援するシステムを開 発・導入した。

5）覚醒下手術用タスク提示・記録装置 IEMAS

重要な脳機能を温存するために術中に患者を覚醒 させタスク評価を行う覚醒下手術での言語タスク提示 時に、神経刺激位置・提示タスク・患者状態・患者反 
応・医師の判断結果をまとめて記録することで、術中 検查結果の誤認防止と迅速・正確なレビューを実現 するシステム、Intraoperative Examination Monitor for Awake Surgery (IEMAS)を開発し導入している。

6) 手術戦略デスク

手術室内に分散して存在する診断・作業情報と、 術前診断情報を統合提示して俯瞰的な治療情報把 握を可能にし、術中手術戦略構築・更新を支援する 手術戦略デスクシステムを開発し試験運用を行ってい る。

これらの技術は、術中に利用可能な情報 modality 医師及びスタッフにわかりやすくかつ正確に伝達すること を目的としている。悪性脳腫瘍の外科的治療において、 Multimodality 情報を駆使した情報誘導治療技術は、治 療成績向上に直結寸る 1)切除率の最大化と、2)手術合 併症の軽減をサポートする。

\section{3.おわりに}

CAS 技術を駆使した情報誘導治療はすでに研究室レ ベルの研究開発段階から、実際の手術室内での臨床研 究・応用の段階に到達している。本報では脳腫瘍外科に おける一例をしめし、これらの技術研究が臨床的に非常 に重要な地位を示す可能性を紹介した。術中 MRI に関 してのみでも国内数施設で新たな臨床応用準備が進め られている現在、脳腫瘍外科および本施設のみならず、 他分野及び国内外の多くの施設で情報誘導技術を駆 使した先端医療が実現されることを期待している。また、 コンピュータ外科学に取り組む諸兄の成果が、国民の健 康向上に直接的に貢献する時代にむけ、本分野の発展 を願ってやまない。

\section{文献}

1) 中村亮一、村坦善浩、伊関洋、術中 MRI 手術環 境、医科器械学、2005; 75(5):248-255

2) 東京女子医科大学 先端生命医科学研究所先 端工学外科学分野 http://www.twmu.ac.jp/ABMES/FATS/

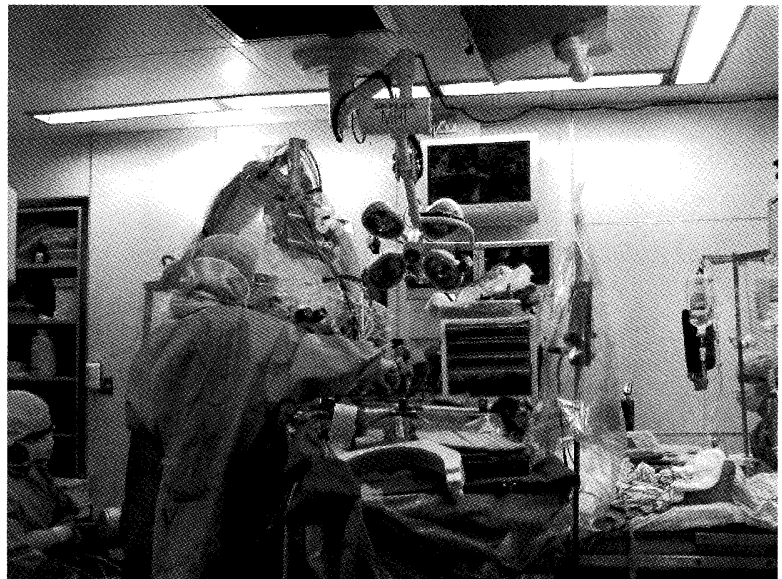

Fig.1 Glioma Surgery in Intelligent Operation Theater

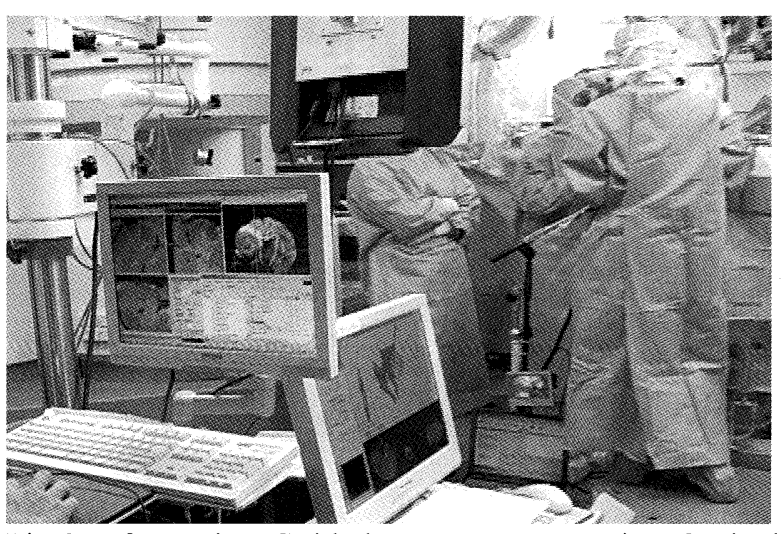

Fig.2 Information Guided Neurosurgery using Optical Navigation System 


\title{
耳鼻咽喉科におけるナビゲーション手術
}

\author{
友田 幸一、村田 英之 ${ }^{a}$ 、石政 寛 ${ }^{a}$ 山下 樹里 ${ }^{b}$ \\ a 金沢医科大学感覚機能病態学耳鼻咽喉科 \\ b 産業技術総合研究所
}

\section{Image-guided Navigation Surgery in Otorhinolaryngology}

\author{
K.Tomoda ${ }^{\text {a }}$, H.Murata ${ }^{\mathrm{a}}$, H.Ishimasa ${ }^{\mathrm{a}}$, J.Yamashita ${ }^{\mathrm{b}}$ \\ a Department of Otolaryngology, Kanazawa Medical University, Ishikawa, Japan \\ b National Institute of Advanced Industrial Science and Technology, Tsukuba, Japan
}

\begin{abstract}
At present, the navigation operation is carried out within the domestic otolaryngology facilities in the about 30 facilities. Though at the beginning as an operation object, it has been used for nose paranasal sinuses operations, the indication is expanded today, and it is otherwise applied to biopsy, surgical education and training, otology and temporal bone operation, head and neck and skull base operation, jaw and face operation and telemedicine. The total number of navigation operation in 29 facilities in Japan until 2003 was 1264 cases, and the nasal operation were 904 $(71.5 \%)$, next head and neck and skull base operation of $181(14.3 \%)$ and order of otology operation of $179(14.2 \%)$. The common indication in these operations are 1) revision case in which the anatomical landmark was lacking and postoperative of the radical operation, etc, 2) serious, invasive and multiple lesions, for example multilocular cyst of paranasal sinuses, etc., 3) the anomaly cases. This time, I would separate the indication from the requirement of the navigation operation on the nose paranasal sinus disease by the rank, and the case is concretely presented. Comparatively cystic disease in nose paranasal sinus disease regards it as a good indication. Then, I want to also introduce new ESS surgical education and evaluation system using the navigation a little.

Key words: Computer aided surgery, Otorhinolaryngology, Paranasal sinus, Surgical education
\end{abstract}

\section{1.はじめに}

現在、日本の耳鼻咽喉科主要医療施設の内、約 30 施設でナビゲーション手術が行われている。数 多くの報告から、その有用性は誰しも認めるとこ ろとなってきているが、今回、鼻・副鼻腔領域の 手術を中心にあらためて以下の項目、1）ナビゲ ーション手術は必要なのか、2）どのような機種 が良いのか、3）どのような手術で必要なのか、 4 ）鼻科手術教育への応用について検討した。

\section{2.ナビゲーション手術は必要なのか}

今回、術者自身がどれほど正確に術中の解剖位 置を認識しているかを検証してみた。内視鏡下鼻 内手術（ESS）のVTR を見てもらいプローブをいろ いろなランドマークに当て、その部位を患者の CT フィルム上で正しいと思われるところを示しても らった。対象は初級（経験 3 年）、中級（経験 5 $\sim 6$ 年) 、上級（経験 10 年以上）の医師に同じ条 件で行った。その結果、初級者は 4 $5 \mathrm{~mm}$ の誤差 が、中級者は $2 \sim 3 \mathrm{~mm}$ の、上級者は $1 \sim 2 \mathrm{~mm}$ の䛊 差のあることがわかった（Fig 1)。ちなみにこの ときのナビゲーションシステムの誤差は $0.6 \mathrm{~mm}$ で あった。解剖部位によっては誤差に大きな違いの 出ることも明らかとなった。知識差、経験差によ る自分の精度を客観的に評価することはこれまで 困難であったが、ナビゲーションシステムを応用 することで簡単に行え、自己点検、自己評価につ ながるものと考える。この結果を踏まえて術前に
自分の精度を確認する必要があり、また術者の誤 差をできるだけ補完する意味でナビゲーションシ ステムの使用は有用と考える。また特にハイリス ク症例では安全で確実な手術を行うためにナビゲ ーションシステムの使用は必須と考える。

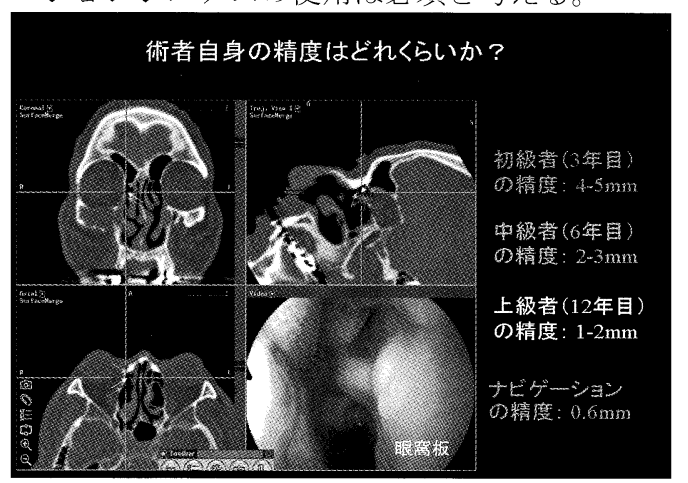

Fig 1, The accuracy of surgen's himself

3.どのような機種が良いのか

2003 年に全国の主要病院耳鼻咽喉科（202 施設） にアンケート調査を行い、回答の得られた 98 施設 の結果 ${ }^{1)}$ から、ナビゲーションシステムを使用し たことのある施設は 29 施設で、使用された機種は 光学式が圧倒的に多く、次に磁気式、アーム式の 順であった。また脳外科、整形外科と共有してい る施設（14 施設）が多かった。レジストレーショ ンの方式、時間については、マーカー法が 20 施設、 サーフェイス法が 14 施設、オートレジストレーシ ヨン法が 4 施設であった。レジストレーションに 要した時間 (平均) は、10 分以内が 5 施設、10〜 
20 分が 14 施設、20 分以上が 6 施設で、最長は 60 分というのが 1 施設あった。これはレジストレー ションの慣れ（使用頻度の多さ）に影響するもの と考えられる。また領域によって、鼻科手術では 20 分以内と短いが、耳科および頭頸部手術ではそ れよりも長く、誤差によっては再度レジストレー ションを行う必要があった。

問題点の多くは、レジストレーションの時間と、 誤差に集約できる。前者はすでに述べたが、後者 については、各施設で大きく異なり $1 \mathrm{~mm}$ 以下の所 から 4-5m m の施設まであり、大体 $2 \mathrm{~m} \mathrm{~m}$ 前後が約 20 施設ともつとも多かった。特に耳科手術と頭蓋 底手術において深部で誤差が大きくなる傾向がみ られている

将来は、レジストレーションの簡便化、機器 の小型化（モバイル型ナビ）、危険エリアでのア ラーム機能、画像としてトラッキングシステムの 採用、3D 画像や VR 画像の応用、さらにシステムと してリアルタイム性を追求した超音波ナビゲーシ ヨンあるいは複合システムの開発、さらに低価格 化などが望まれるが、おそらく使用用途によって 大きく二極化されるように思われる。一つはさら に精度が向上し、機能も付加され、大学病院レベ ルの高度な手術に対応した機種と、もう一つは不 必要な機能は取り除かれ、簡便で操作性に優れ、 外来、診療所レベルなど、いつでもどこでも使え るように持ち運びができるような小型のモバイル 型の機種である。

\section{4.どのような手術で必要なのか}

手術対象としては、当初、鼻副鼻腔手術に使用 されたが、今日その適応は拡大され耳科・側頭骨 手術、頭頸部・頭蓋底手術、顎・顔面手術の他に 生検、手術教育、トレーニング、遠隔医療にまで 応用されてきている。全国 29 施設のナビゲーショ ン手術の件数は 1264 件で、領域別では鼻科手術が 最も多く 904 件 $(71.5 \%)$ 、次に頭頸部・頭蓋底手 術 181 件 (14.3\%)、耳科手術 179 件 $(14.2 \%)$ の 順であった。鼻科手術 904 件の内訳を見ると、慢 性副鼻腔炎と囊胞性疾患で 9 割以上を閉めている。 さらに当科で行った鼻副鼻腔手術（185 例）の内訳 とナビゲーションの必要度をランク分けしてみる と、Fig. 2 に示したように、慢性副鼻腔炎 (再手術) で 36\%が絶対に必要であり、あったほうが良かっ た例は $61 \%$ で、その理由は眼窩、視神経の確認の ために必要であった。副鼻腔囊胞では、22\%が絶 対に必要であった。その理由は多胞性の囊胞、前 頭洞囊胞、骨性に閉鎖された小さな囊胞の場合で ある。さらに先天性の後鼻孔閉鎖例で特に骨性閉 鎖の場合は絶対適応と考えられた。

\section{4. 鼻科手術教育への応用}

産業技術総合研究所 (山下ら ${ }^{2)}$ ) によって開発さ れた精密ヒト鼻副鼻腔モデルとナビゲーションシ ステムをドッキングさせ、イメージガイド下に行 う内視鏡下鼻内手術トレーニングシステムを考案
した（Fig. 3)。このモデルは正常者のCT画像から 作成され、構造的に非常に正確に忠実に作られて いる。このシステムを用いることにより研修医が 実際の画像と平行して手術体験を繰り返し行うこ とができ、また解剖学的知識の習得とスキルの向 上に役立つものと考える ${ }^{3)}$

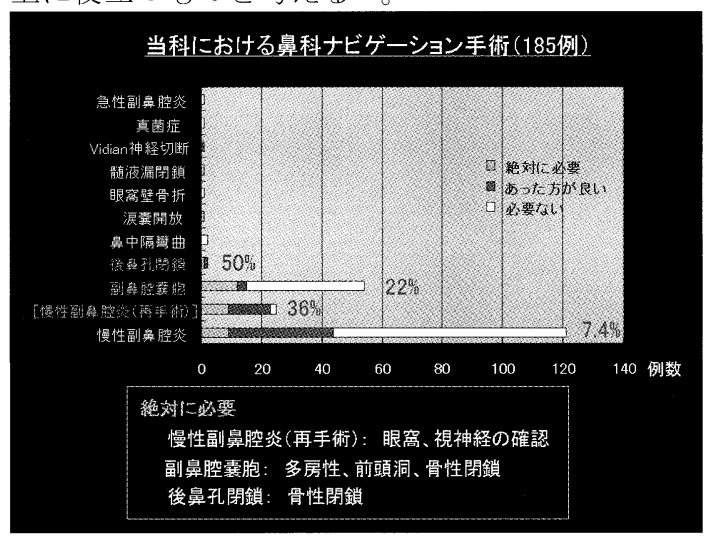

Fig. 2 Ranking of indication for nasal navigation surgery

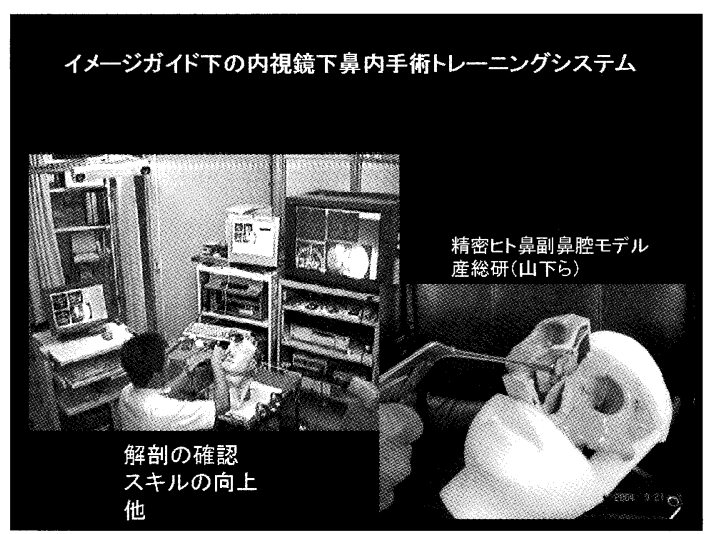

Fig. 3 Image-guided endoscopic endonasal surgery training system

謝辞

ナビゲーションアンケート（2003 年）にご協力 いただいた全国 29 の耳鼻咽喉科施設に深謝いた します。

参考文献

1）友田幸一、石政 寛：ナビゲーション手術の 現状一全国主要施設耳鼻咽喉科アンケート結 果より一。耳展 47:336-340、2004

2）山下樹里：「世界初、内視鏡下鼻内手術于技 トレーニング用「精密ヒト鼻 腔モデル」の開発」、AIST Today Vol. 3, No. 6, pp. 14-17, 2003.

3）竹村 博一 村田 英之 石政 宽 友田 幸一：精密ヒト鼻腔モデルを用いたナビゲ ーション下鼻内内視鏡手術の教育・トレーニ ングシステム。耳展 $47: 377-379 、 2004$ 


\title{
05(VS)-3
}

\section{腹部外科領域におけるコンピュータ外科手術の実際}

\author{
○橋爪 誠 \\ 九州大学大学院災害救急医学、九州大学病院先端医工学診療部・救急部
}

\section{Computer-Aided Surgery in General Surgery}

\section{Hashizume}

Department of Disaster and Emergency Medicine, Graduate School of Medical Sciences, Kyushu University, Fukuoka, Japan

Departments of Integration of Advanced Medicine and Innovative Technology, and Emergency Medicine, Kyushu University Hospital, Fukuoka, Japan

\begin{abstract}
Computer-aided surgery includes robotic surgery, pre-operative surgical planning system, intra-operative surgical navigation system, simulation system and so on. The purpose of the computer-aided surgery is to assist surgeons to accomplish safer and more precise surgery, especially in minimally invasive surgery. The number of installation of the da Vinci surgical robotic system is now more than 300 in the world. Complicated procedures of endoscopic surgery are easily performed by introducing the robotic surgical system because of its easier operability.
\end{abstract}

Key words: da Vinci surgical robotic system, navigation system, simulation system

\section{1. はじめに}

腹部外科領域では、1987年に腹腔鏡下胆囊摘出術が 世界で初めて施行されて以来、全世界に内視鏡外科手 術が普及し、低侵襲治療への傾向は益々高まっている。 戦時の遠隔手術支援開発の中から生まれた手術支援口 ボットは、同時期に発展した低侵襲治療を目指した内視 鏡外科手術の技術的困難を克服するものとして一躍脚光 を帯び、安全で安心して受けることのできる外科治療を支 えるものとして益々の発展が期待されている。

\section{2. コンピュータ外科手術の動向}

腹部外科手術領域では、ダビンチ(Fig.1)、ゼウス、ナビ オットなどの手術支援ロボットが実際に商品開発され臨床 応用されている。現在最も普及しているのは、米国ベンチ ヤー企業Intuitive Surgical社が開発したダビンチで、すで に設置台数は全世界で300台を超え、米国がこの内の 200 台以上を占めている。消化器領域だけでなく、心臓手術 や、前立腺手術、産婦人科手術などもFDAの認可を既に 得ている。

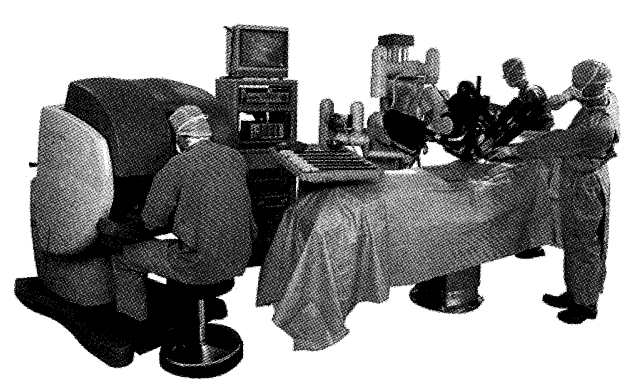

Fig. 1 da Vinci

一方、血管造影や，MRI、CTなどの術前画像の3D表 示が容易にできるようになり、治療対象部位の正確な位置 の確認や、治療のアプローチの仕方などの術前計画とし て、内視鏡外科手術で利用されることが次第に増えてきた。 また、治療中の治療精度の向上と、手術ミスや合併症を減 少させる目的でナビゲーションシステム(Fig. 2)が利用され 始めている。 


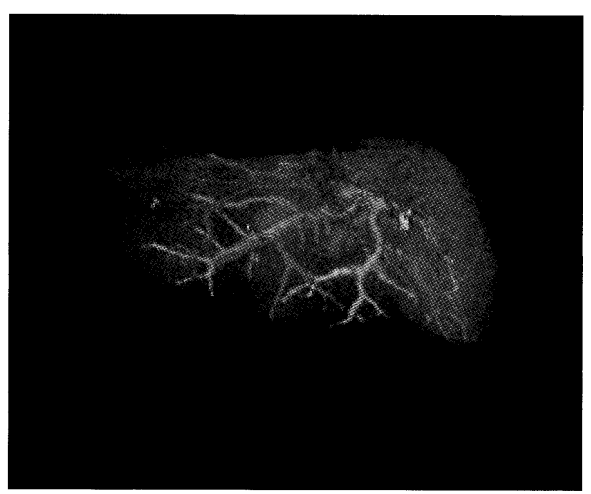

現在、将来の外科医の教育訓練を見据えた教育システム として、手術シミュレーションシステム(Fig. 3)が研究開発さ れている。今後、医学生や研修医の教育訓練の他、術前 の外科医の手術の訓練や、術中の模擬手術として普及し ていくことが予想される。

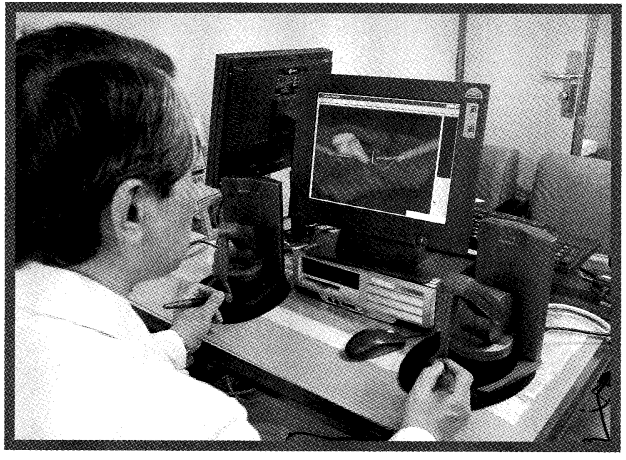

Fig.3: Surgical simulation system

\section{3. 治療の実際}

腹部外科領域でのロボット手術は、内視鏡外科手術に おいて縫合・結紮など複雑な手術操作を必要とする術式、 特に前立腺全摘術や、胆道系手術、膵切除術、腎移植の ドナー手術など非常に多くの低侵襲手術に応用されてい る(Fig. 4)。しかし、従来の手術支援ロボットには、触営情 報や力覚情報を術者に伝える事ができないために、初め は組織を不必要に挫滅したり、系を切ったりすることがある が、画像誘導装置を設置することで、より確実な手術が可 能となる(Fig.5)。
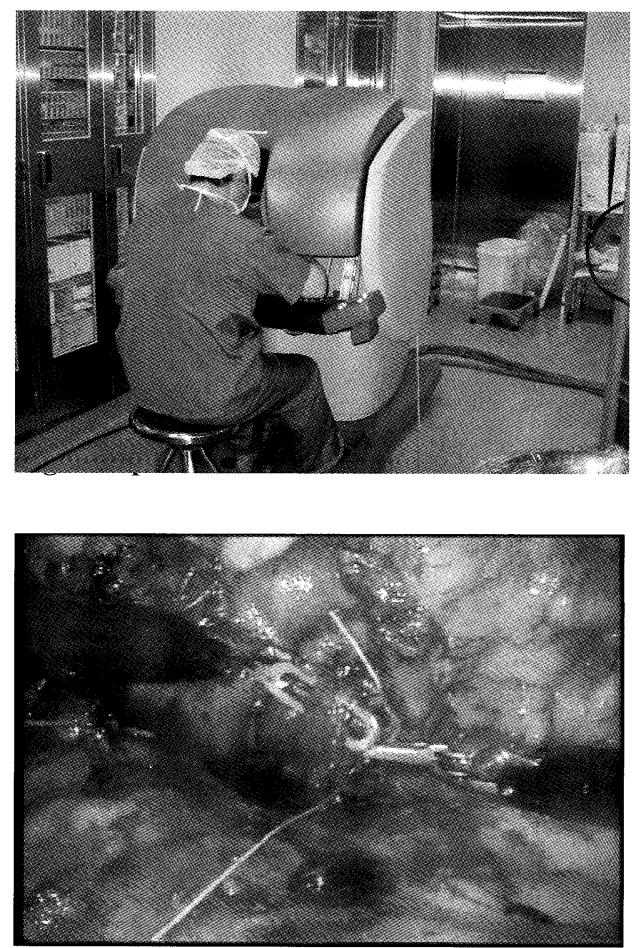

Fig. 5: Ligation of the vessels by the da Vinci

4. おわりに

コンピュータ外科手術は、今世紀の医療が目標とする患 者に優しい医療を実現するためのツールとして、ロボット 手術だけでなく、ナビゲーションシステムや、シミュレーショ ンシステムなどの発展とともに益々発展するものと確信す る。 


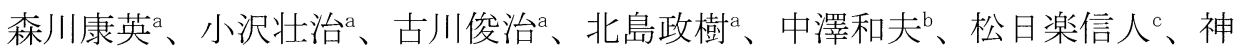
野誠

$a$ 慶應義塾大学外科学教室 、 $b$ 同理工学部システムデザイン工学科、 $c$ 東芝 R\&D センター

\title{
Development of the Master-Slave Combined Manipulator (MCM robotic forceps).
}

Yasuhide Morikawa ${ }^{a}$, Souji Ozawa ${ }^{a}$, Toshiharu Furukawa ${ }^{a}$, Masaki Kitajimaa, Kazuo Nakazawa ${ }^{b}$, Nobuto Matuhira ${ }^{c}$, Makoto Jinno ${ }^{c}$

${ }^{a}$ Keio University School of Medicine,Department of Surgery

${ }^{b}$ Keio University,Department of System Design Engineering

${ }^{c} R \& D$ Center,Toshiba Company

\begin{abstract}
A master-slave combined manipulator (MCM robotic forceps) for laparoscopic surgery that enhances surgeons' skill has been developed. The forceps has 7 degree of freedom and the position of the master is figured out and transmitted to the controller through potenciometer and the slave moves exactly the same motion with the master grip. The position of the slave was measured by the encoder and feed-backed to the system. The MCM forceps gives $7 \mathrm{~N}$ of tying force which is satisfactory for usual suturing procedure.MCM gives surgeons more freedom in performing laparoscopic surgery especially with suturing and tying. Surgeons are now able to place stitches from any desired direction without restriction by port site.
\end{abstract}

Key Words: Master-Slave Combined Manipulator, Laparoscopic Surgery, Robotic Forceps

1.はじめに

内視鏡下手術はその低侵襲性から多くの分野で採用さ れているが、従来のす心゙ての術式に取って代わるまで には至っていない。その大きな原因は自由度の不足と 触覚の欠如である。この二つの险路を解決し、実際の 臨床に役立てるために検討を行ってきた。自由度の不 足のためにはすでに国外でマスタ・スレーブマニピュ レータ型の手術ロボットが開発されており、いくつか の施設で臨床応用がおこなわれ、優れた操作性と自由 度が評価されている。一方、我々はこの使用経験を通 じて消化器手術の立場から鉗子部と操作部が一体とな ったMCMロボット鉗子の開発を1998年より行ってきた。 その理由は、これまでの手術ロボットは大型で複雑な 機構を有し、鉗子相互の干渉や術野の再設定に不自由 があること、そして何よりも患者の傍らに術者がいる
ことができず、術野全体が機器に覆い隠されてしまう ためその安全性にも不安があるためである。このロボ ット鉗子は, 従来の器具では不可能であった方向から の縫合を可能とするロボティックツールであり、これ までエキスパートによる操作性評価や動物実験などの 実績を通じて、その有望性，将来性において多くの期 待を得られたため、現在製品化を目指して準備段階に ある。

\section{MCM鉗子の基本機構}

本鉗子ではマスタ部とスレーブ部をそのまま鉗子の一 部としてつなぐ従来の腹腔鏡手術用鉗子と同様の外観 を有している。その理由の一つは鉗子大きな動き（直 動、pitch，yaw，roll）を術者自身の腕の動きに委秝 つつ、自由度を先端に確保することにある。このMCM 
鉗子は操作部に 3 関節、鉗子部に 3 関節を有し、鉗子先 端にグリッパー軸、yaw軸（またはpitch軸）およびrol1 軸の3自由度を得ている。操作部のそれぞれの軸の位置 はポテンシオメーターによりコントローラーに伝えら れ、モータードライバーにより所望のトルクにより鋤 子に伝達される。鉗子のそれぞれの自由度の位置は工 ンコーダによりコントローラに伝達され、位置制御に よるユニラテラルコントロールを採用している。これ までに径 $10,5,3 \mathrm{~mm}$ の鉗子の試作を行い現在 $5 \mathrm{~mm}$ 径の 鉗子により市販モデルの製作を開始した。その基本性 能は表 1 に示すが、 $5 \mathrm{~mm}$ 鉗子の先端把持力は6-7Nを達 成している。しかし、一体型構造であるためにpitch とyawを同時に実現することができず、さらに特異姿勢 における動作制限もある。

\section{3. 縫合、結紮作業とMCM鉗子}

ファントム（スポンジ製臓器モデル）の任意の位置に 対して縫合結杽作業が可能であるか確認した。結禁 作業は，平結びを 3 回行い，そのうち最初の 1 回を 2 重ループにする外科結紫とした。MCM鉗子はトロカール 挿入部に規定される従来の腹腔鏡鉗子に比心゙、腹壁の 固定点に制限を受けることなく、あらゆる方向から針 の刺入が可能であり、先端の自由度により縫合操作も 容易である。すでに腹腔鏡下噴門形成術への臨床応用 がおこなわれており、今後の利用が期待される。

なお，本研究はNEDO「内視鏡等による低侵襲高度手術 支援システム」(H12-H16)により開発したものである.

\section{文献}

1) Matuhira N., Jinno M., Morikawa Y. et

al. : Development of a functional model for a master-slave combined manipulator for laparoscopic surgery. Advanced Robotics, Vol. 17, No. 6, pp. $523-539$ (2003)

2) 神野ほか 9 名：腹腔鏡下于術支援用一体型マスタス レーブマニピュレータの開発（縫合結紮作業の操作性 評価），日本機械学会ロボティクス・メカトロニクス
講演会講演論文集，1P1-B05 (2002).

3) 神野ほか 9 名：腹腔鏡下手術支援用ロボット鉗子の 細径化モデルの開発，日本機械学会ロボティクス・メ カトロニクス講演会講演論文集， $2 \mathrm{~A} 1-2 \mathrm{~F}-\mathrm{C} 7$ (2003)

Table 1 Specifications of the robotic forceps

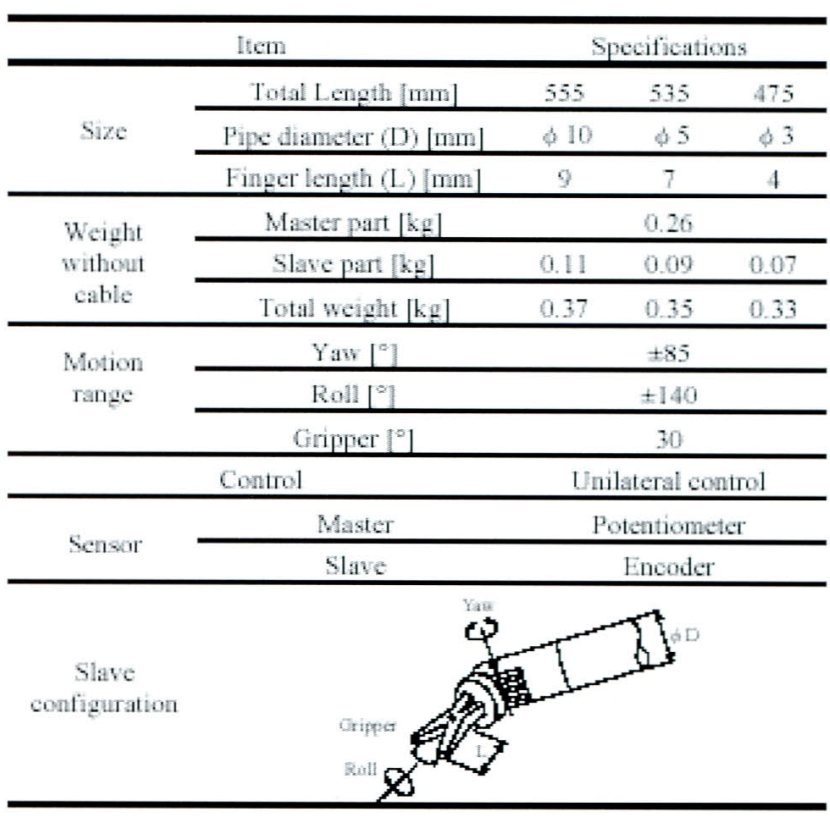

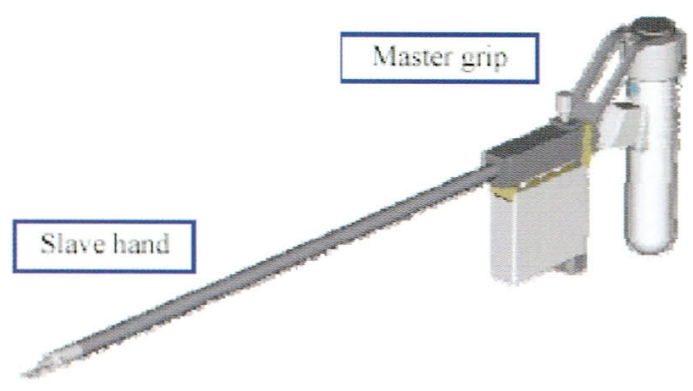

Fig1.MCM robotic forceps

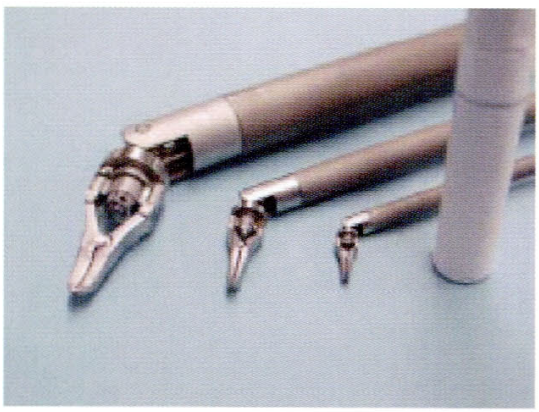

Fig. 2 Robotic forceps (10mm, $5 \mathrm{~mm}$ and $3 \mathrm{~mm}$ in diameter) 
○来見良誠、仲 成幸、塩見尚礼、出村公一、佐藤浩一郎、村上耕一郎

Hasnine A Haque*、森川茂廣*、犬伏俊郎*、谷 徹

滋賀医科大学外科学講座、滋賀医科大学MR医学総合研究センター*

\section{Clinical Application for Hepatic Cancer using real-time MR Navigation}

Y.Kurumi, S.Naka, H.Shiomi, K.Demura, K.Sato, K.Murakami,

Hasnine A.Haque ${ }^{* *}$, S.Morikawa*, T.Inubushi*, T.Tani

Department of Surgery, Shiga University of Medical Science

MR Science Research Center, Shiga University of Medical Science*

GE Yokogawa Medical Systems**

Abstract:

Treatments for hepatic tumors using real-time MR navigation system have been carried out for 5 years. In this period, we have developed new surgical procedures, new MR compatible surgical instruments and navigation software by ourselves. Such devices, for example Endoscout ${ }^{\mathrm{TM}}$ system and 4D-MR navigation, have been increased the availability of MR-navigated procedures and quite effective for the accurate and safe treatment. I introduce some clinical cases using real-time MR navigation.

\section{【はじめに】}

垂直型オープンMR装置（GE 社製 Signa SP/i）は、手 術中にMR画像を撮像することが可能な装置で、当院では 2000 年 1 月より臨床稼働している。安全性と治療精度の 向上のために様々なソフトウェアおよび治療器具を開発 していることはすでに発表しているが、本稿では、最新の センシングシステムと高精度の穿刺手法を中心に、ビデオ を用いて供覧する。

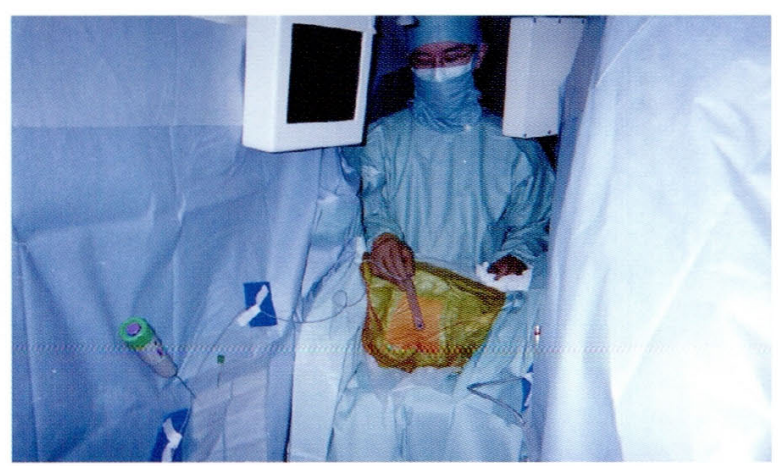

Fig.1 MR-MCT using Endoscout

当科では、肝腫瘍に対寸るマイク口波凝固療法に対し、 リアルタイム MR による術中画像ナビゲーションを用い てきた。術者はニードルガイドとなるハンドピースにより トラッキングされた任意断面のリアルタイムM R 画像に より肝腫瘍を穿刺する。この際、従来用いてきた赤外線 LED システムを用いた Flash point ${ }^{\mathrm{TM}}$ system によるトラ
ッキングでは、赤外線感知装置と八ンドピースの間が遮蔽 されるとトラッキングできなくなる欠点があった。 EndoScout ${ }^{\mathrm{TM}}$ system は MRI 撮像時の傾斜磁場を感知し て位置情報を得るため、ハンドピースの遮蔽によるトラッ キングの中断がなく、任意の位置で安定したトラッキング

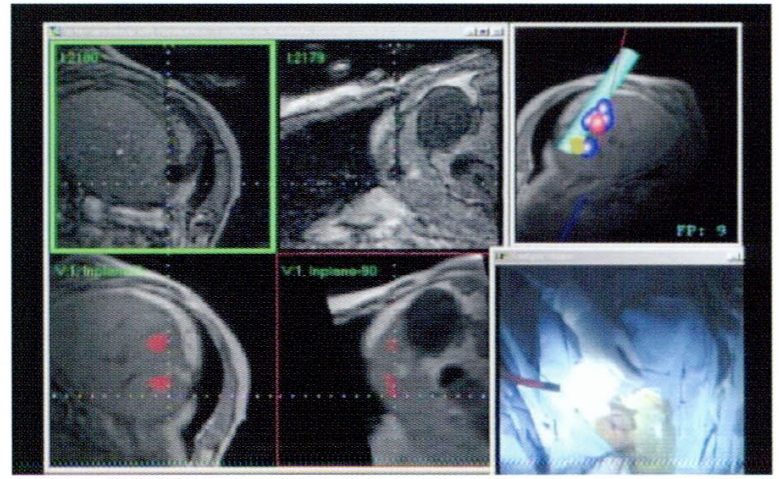

Fig.2 MR-Navigation System が可能である。(Fig.1,2）

【方法】朋癌症例に対し垂直型オープンMR I (Signa s/p: GE）によるマイクロ波凝固療法を行った。Endoscout ${ }^{\mathrm{TM}}$ による 3 次元トラッキングシステムは、術中リアルタイム MR I 撮像時の、XYZ のそれぞれ 3 方向の傾斜磁場の変 化をハンドピース内に内臓された直行する 3 対の直径約 $7.4 \mathrm{~mm}$ のコイルによる起電力の変化によりハンドピース 
の位置掞よび向きを検出するものである。この Endoscout ${ }^{\mathrm{TM}}$ System からの位置情報により、術中モ二タ 一上に任意断面のリアルタイムMR画像が表示される、術 中ナビゲーション走行った。また、治療精度向上のために 手術支援 4 次元画像老導入 L M R - MC T 施行した。術 中 4 次元画像表示は過去画像 - 現在画像 - 未来画像孝 1 画 面 6 分割同時同期表示としている。MR 手術室内で治療直 前に詳細な $3 \mathrm{D}$ バーチャル画像（過去画像）を作成し、 FSPGRによるリアルタイム画像（現在画像）と、断層面を 同期させた 3 D バーチャル画像に未来イメージ(未来画像) を作成する。次に近未来画像をリアルタイム画像と同期さ せて表示する。リアルタイム画像と近未来画像を用いて夕 一ゲットを検出すると、この時点で現在画像・過去画像・ 近未来画像・未来画像が同時表示される。(Fig. 3, 4)

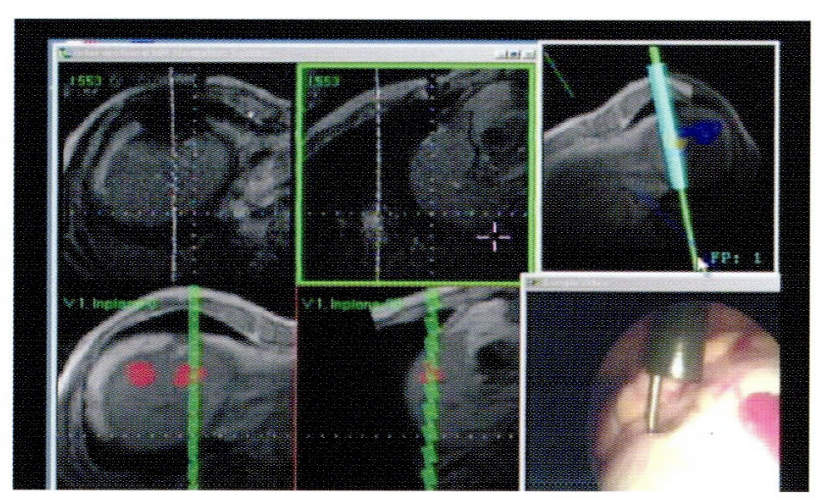

Fig.3 4D-MR Image Navigation

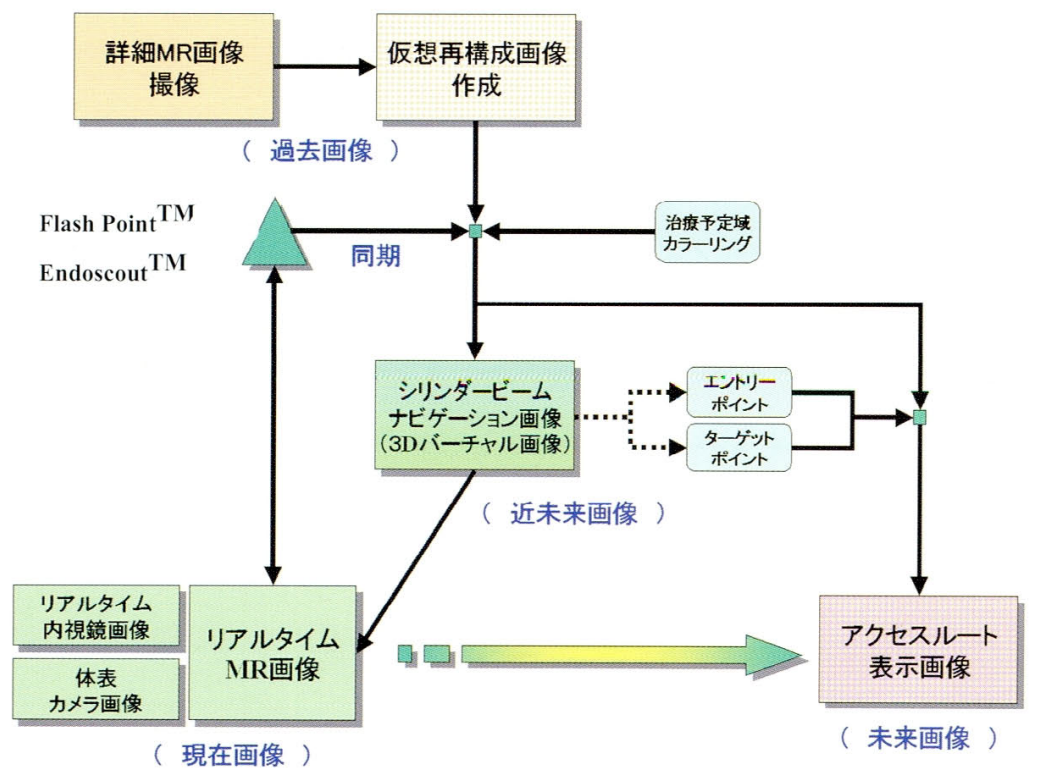

Fig.4 4D-MR Navigation System
【結果】全例に対し術中MR I ナビゲーションによるマイ ク口波凝固療法が可能であった。Endoscout ${ }^{\mathrm{TM}_{\mathrm{syste}}}$ は 従来の Flash pointによるナビゲーションに比べ、ハンド ピースの遮蔽による位置の制限がないため、穴定したナビ ゲーションが可能であった。従来は術者の勘に頼っていた 穿刺手技が、時間軸を有した 3 D 画像画像（4次元画像） として明瞭に表示されるため、より精度の高い確実な MR-MCT が可能になった。

【結論】現在までに当院で開発した術中MR I ナビゲーシ ヨンシステムは、肝腫瘍に対しあらゆる方から慗刺ルー 卜等の安定したナビゲーションが可能となり有用なシス テムであると考えられる。

\section{【文献】}

1) Y.Kurumi, S.Morikawa, S.Naka, et al:Robotic Surgery for Cancer: New Perspectives in Cancer Research and Therapy, 59-70, 2005

2) S.Morikawa, T.Inubushi, Y.Kurumi,et al: Advanced computer assistance for magnetic resonance-guided microwave thermocoagulation for liver tumors. Acad Radiol 2003; 10:1442-1449 


\title{
05(VS)-6
}

\section{コンピュータ支援整形外科手術. ロボナビ}

○菅野 伸彦 ${ }^{a}$, 西井 孝 ${ }^{a}$, 三木 秀宣 ${ }^{a}$, 高尾 正樹 ${ }^{a}$, 小山毅 ${ }^{a}$, 花之内 健仁 ${ }^{a}$,

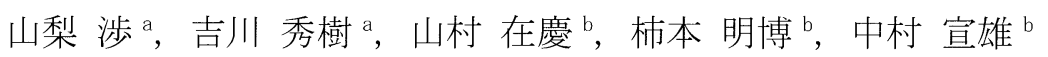

a 大阪大学大学院医学系研究科 器官制御外科学, 協和会病院 人工関節センター

\section{Computer Assisted Orthopaedic Surgery. Robo-Navi}

N. Sugano ${ }^{\text {a }}$, T. Nishii ${ }^{\text {a }}$, H. Miki ${ }^{\text {a }}$, M. Takao ${ }^{\text {a }}$, T. Koyama ${ }^{\text {a }}$, T. Hananouchi ${ }^{\text {a }}$, W. Yamanashi ${ }^{\text {a }}$, H. Yoshikawa ${ }^{a}$, M. Yamamura ${ }^{b}$, A. Kakimoto ${ }^{b}$, N. Nakamura ${ }^{\text {b }}$

${ }^{a}$ Department Of Orthopaedic Surgery, Osaka University Graduate School of Medicine, Suita, Japan

${ }^{b}$ Center for Arthroplasty, Kyouwakai Hospital, Suita, Japan

\begin{abstract}
Computer assisted surgery (CAS) systems such as preoperative planner, surgical navigation, and surgical robot are being used in various types of orthopaedic surgery. In this video symposium, minimally invasive total hip arthroplasty is presented using an active robot (ROBODOC) and a CT-based navigation system (Stryker Navigation). These CAS systems, their potential, and their limitations are reviewed here. Future technologies and future directions of CAS that will help provide improved patient outcomes in a cost-effective manner are also discussed.
\end{abstract}

\section{【はじめに】}

近年, コンピュータ技術を駆使した種々の手術支援システ ムが整形外科手術用に開発され，臨床的にも使用されている。 コンピュータ手術支援には，1) 手術計画, 2)手術ナビゲーシ ヨン，3)手術支援ロボット，4)動作解析などがある.これらのコ ンピュータ手術支援システムは, 共通して患者の 3 次元的形 態情報や機能情報をもとにコンピュータ上で診断治療計画を 立案し, 術中骨格の位置を計測しながらこれらの情報を患者 自身に重放合わせて使用している. また, 術後のリハビリ指導 や機能解析にも使用できる. 形態情報源としては, X 線 CT (Computerized Tomography)が最も頻繁に使用されている. 本ビデオシンポジウムでは, コンピュータ手術支援システムを 用いた整形外科手術のなかで, 人工股関節全置換術につオ 一カスし, 低侵襲手術を目指し最小皮膚切開で手術支援口ボ ットとナビゲーションを用いた手術の実際を紹介し, 残された 課題と将来の方向性について述べる.

\section{【使用機器および手術の実際】}

人工股関節全置換術は, 変形性股関節症などの関節疾 患や外傷により変形した股関節に, 正常な股関節と同じボー ルとソケットの形状をした人工関節を移植するものである(Fig. 1). 骨盤側に半球状のソケットが固定され, 大腿骨側にボー ルを支えるステムを固定することで, 歩行などの運動時にボー ルとソケットのみが摺動し，人工関節と骨とが動かないことで痛 みのない動作が可能となる. 人工関節と骨との固定には骨セ メントと呼ばれるポリメチルメタクリレートといら 10 分ほどで液体 から固体となる樹脂を隙間に充填して固定されていたが，人 工関節の形状どおりに骨を掘削する術具の進歩と金属材料 に骨新生を誘導する表面コーティング技術の進歩により, セメ ントレスの人工股関節が急速に普及してきている. セメントレス 人工股関節は初期固定に成功すれば, 摺動部の磨耗やイン ピンジメント, ステムの疲労折損, 大腿骨の力学的環境変化
(ストレスシールド)による局所的菱縮(骨量減少)などが再手 術を必要としないための課題であり, これらを解決するための 材料やデザインの改良により，20 年以上機能し続けることが 期待できるようになってきている.このようなインプラントのデザ インには, CT データを用いた 3 次元的な骨形態解析が重要 で, 解剖学的解析に基づくデザインは, 骨とのフイットがよくス トレスシールド軽減や関節可動性の向上もたらす ${ }^{1)}$.このような Computer Aided Design / Computer Aided Manufacturing (CADCAM)を用いたハイテクデザインの人工関節も，それを 取り付ける骨の掘削や切除などの加工がローテクでは, 十分 な初期固定が得られず, 手術の成功率も低下寸る. そこで, 手術室に骨の整形のために CADCAM を持ち込んだのが手 術支援ロボットの ROBODOC である.

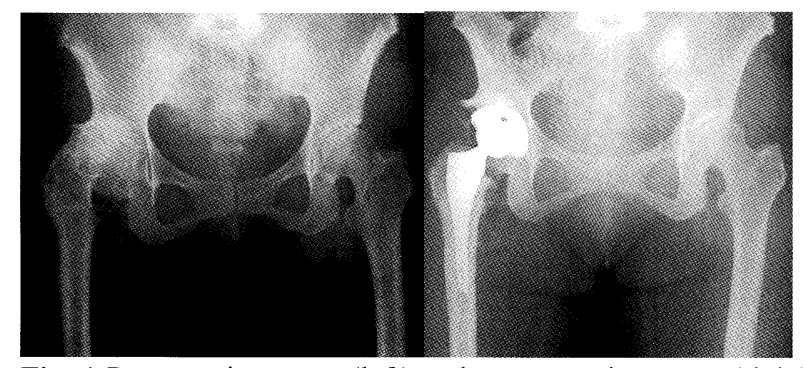

Fig. 1 Preoperative x-ray (left) and postoperative x-ray (right). The preoperative $x$-ray shows severe deformity of the right hip due to osteoarthritis. Cementless total hip arthroplasty was performed using an anatomic prosthesis (CentPillar, Stryker).

人工股関節の手術計画は, 従来単純 $\mathrm{X}$ 線写真に人工関節 の各種サイズの形状を描いたテンプレートを重ねて手書きで 行われていた. しかし単純 X線像は 2 次元投影像で, 拡大率 が一定せず, 複雑な形成を把握するには, 撮影方向の影響を 受けやすくインプラントのサイズや設置位置を術中所見から変 更せざるを得ないことが多々あった. そこで術前に取得した 
CT の画像情報を 3 次元的に再構成し, 任意の直交 3 断面 (MPR) 画像で骨の構造を観察したり,これに人工関節の CAD データを重ねて出力することで, より正確で詳細な手術 計画が立案可能となった(Fig. 2).

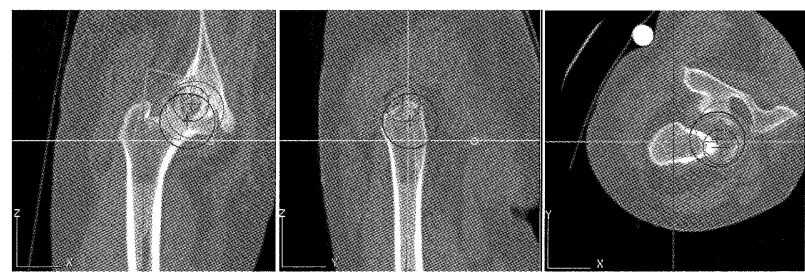

Fig. 2 Preoperative planning with CentPillar on ORTHODOC.

この 3 次元的な立案計画どおりに手術を行うために, 手術 対象の骨を固定し, 装置と剛性フレームを形成し, 剛性フレー ム内の骨と手術計画を含む術前 CT 画像データの位置合わせ (registration)をし, 手術計画通りの位置に人工関節骨母床骨 孔を掘削するロボットが ROBODOC である(Fig. 3).

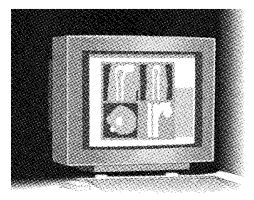

術前3次元CT
術中モニター
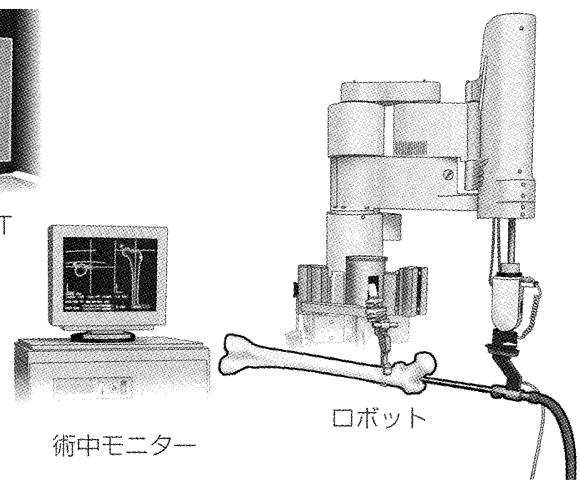

Fig. 3 ROBODOC surgical assistant is a SCARA type 5-axis robot with a bone milling cutter placed at the tip of the robot arm.

5 軸ロボットの先端に力センサーを介して骨掘削ドリルを装 着し, 水流で掘削屑を洗浄し, 摩擦熱による骨の熱損傷を防 止しながら正確な大腿骨髄腔の掘削を行うため, 従来のや寸 りを髄腔に挿入して掘削する力法に比較して術中骨髄組織が 静脈に押し出されて肺に塞栓を起こすことが極めて少ない2).

初期には大腿骨転子下部をクランプして大腿骨とロボットの 剛性フレームを形成していたが，筆者らが低侵襲手術用フレ 一ムを開発したことで，皮膚切開も非常に小さくてすむように なった.

この手術室 CADCAM に対し, Global Positioning System (GPS)に相当するものがナビゲーションである.骨盤側にソケ ットを設置するには，半球状に骨を掘削すればいいので, 複 雑な大腿骨の形状に比較して, 単純な半球状のリーマで整形 できる.しかしながら, リーマの位置や深さを 3 次元的見極める ことは X 線透視を使用しても容易ではない. 骨盤に赤外線発 光ダイオードマーカを装着し，CT 画像から作成した骨盤モデ ルと実際の骨盤を表面形状 registration することで3)，マ一カを 装着したリーマの位置をコンピュータ画面上にCT像や術前手
術計画に重㸚て表示できるので, 小切開でも正確に骨盤に半 球を掘削することが容易となる(Fig. 4).

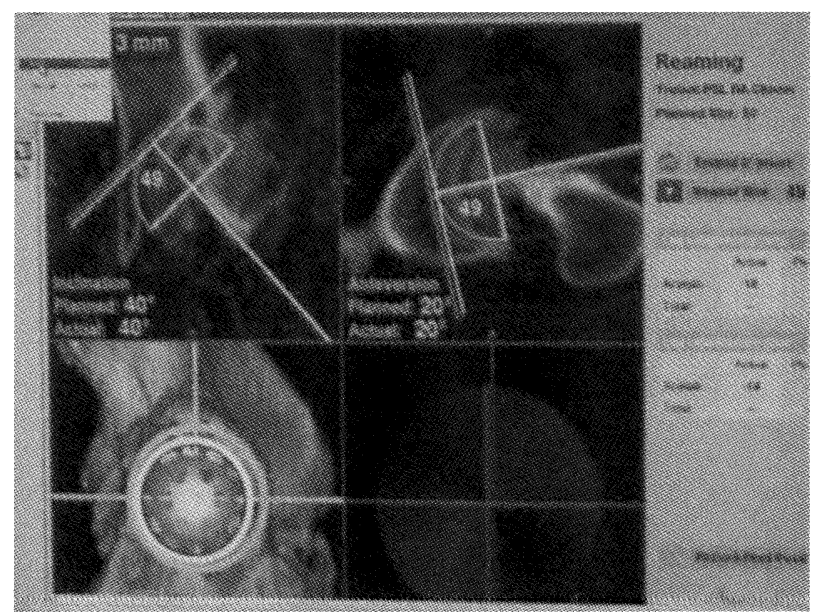

Fig. 4 CT-based navigation for acetabular reaming.

最終的には, ソケットをプレスフィット固定するが, ソケットの 設置角度は術後の関節可動域や安定性に非常に重要である. ナビゲーションでは, ソケット挿入器にマーカが搭載され, ソケ ッ小の角度を見ながら目標角にインパクト固定できる. 設置した 人工関節のサイズ, 位置, 角度は 3 次元的に記録され, 術後 のリハビリや成績評価に活かされる.

\section{【考察】}

手術室にCADCAMやGPSを持ち込んだロボナビ手術は， 個々の患者の術前 CT データからの骨格形態情報に基づい た最適手術計画どおりに, 安全で正確になおかつ低侵襲に 手術を行うことに非常に役立っている. 術前計画どおりに手術 が可能となってくると, 外科医の経験に基づく術前計画からも つと客観性をもたせたコンピュータ手術計画自動支援が今後 開発されるべきである. また,このようなコンピュータ支援シス テムを用いたことのない外科医にとっては, 学習すべきことが 増加するため, 簡単には許容されにくいことが臨床的な課題 である. しかしながら，３次元情報を十分に活かして手術を支 援する装置があれば, 外科医の手術訓練で学習曲線を急峻 にすることにも役立つので, 教育ツールとしても有効に活用で きるものと思われる.

【文献】

1) Noble PC, Kamaric E, Sugano N, et al.: Three-dimensional shape of the dysplastic femur: implications for THR. Clin Orthop Relat Res. 2003 Dec;(417):27-40.

2) Hagio K, Sugano N, Takashina M, et al: Effectiveness of the ROBODOC system in preventing intraoperative pulmonary embolism. Acta Orthop Scand. 2003 Jun;74(3):264-9.

3) Sugano N, Sasama T, Sato Y, et al: Accuracy evaluation of surface- based registration methods in a computer navigation system for hip surgery performed through a posterolateral approach. Comput Aided Surg. 2001;6:195-203. 


\title{
05(VS)-7＜wide>胎児に対するコンピュータ支援手術/治療の可能性
}

\author{
千葉敏雄
}

国立成育医療センター 特殊診療部

\section{Computer Aided Surgical Therapy for Fetuses}

T.Chiba

Department of Strategic Medicine, National Center for Child Health and Development, Tokyo, Japan

\begin{abstract}
Minimally invasive fetal surgery has been developed to avoid complications caused by open fetal surgery. But, some technical problems are associated even with fetoscopic surgery (spina bifida, twin-twin transfusion syndrome) ; placental location, a mobile fetus floating in amniotic fluid, physiologically cloudy amniotic fluid and so on. To overcome these technical problems, surgical assistant systems and devices have been developed in the field of preoperative diagnosis, intraoperative monitoring/navigation and surgical devices. Some recent progresses are presented.
\end{abstract}

Key words: Fetal surgery, Minimally invasive surgery, Spina bifida, Twin-twin transfusion syndrome

\section{1. 背景}

胎児外科手術 ${ }^{122}$ は, 従来は腹壁と子宮壁を切開し 胎児の一部を露出させて治療を行っていた. しかしこの 方式では胎児・子宮への侵襲が大きいため, 早産など の合併症を引き起こす可能性があった. そこで, より低 侵襲に治療を行う手技として, 内視鏡下胎児外科手術 が行われるようになってきた. 内視鏡下胎児手術では, 他の内視鏡手術と共通の問題点に加え, 胎児外科特 有の課題がある. まず, 胎児は非常に脆弱であるのみ ならず, 羊水中に浮遊しているため, 対象部位の固定 が困難である. しかも混濁した羊水中では明瞭な視野を 得ることが困難で, 電気メスなど通常の手術で用いられ るデバイスの作動効率も制限される. また術後の羊水漏 れや羊膜損傷によるリスクを抑えるためには, 子宮壁穿 刺径が 3-4mm以下であることが望まれるが，このような 細い術具で高い操作性を確保することは難しい.

これらの課題を克服するため, 我々は胎览外科を対 象とした工学的支援技術の開発を進めている. 以下に 技術開発の対象としている疾患と, 開発中の技術につ いて述べたい.

\section{2. 対象とする疾患}

双胎間輸血症候群(TTTS): 一䋐毛二羊膜性双胎妊 娠 (胎盤が1つで羊膜は二つの双子)の $10 〜 15 \%$ にみら れる病態であり，両方の児の胎盤血管に吻合が存在す る.これにより二児間に血流のアンバランスが生じ, 受血 児は心不全, 供血児は腎不全の症状を呈するリスクが ある. 本疾患に対しては, 胎盤表面の吻合血管を内視 鏡で観察しながらレーザで凝固し，血流を遮断する治 療が行われる.この手術では, 胎盤表面を走行する多
数の血管から焼灼すべき血管を選別することと, 胎盤表 面とレーザファイバ先端間距離を適切に調節することが 難しい. 特に腹側付着胎盤に対し, 胎盤表面に回りこん でレーザを照射するには熟練を要する。

二分脊椎症: 脊椎骨の形成不全により神経が一部背 部に露出する疾患であり, 生後, 下半身運動障害や脳・ 膀胱・直腸の機能障害をおこすことがある. 本症例に対 する胎児期治療としては, 露出した神経を保護し髄液 流出を防ぐことを目的に, 露出部の縫合やパッチ貼布 固定による被覆が試みられている。しかし, 脆弱な皮膚 組織の胎児に対して, 縫合などの外科的手技を行うこと は多くの困難を伴う。

\section{3. 提案する胎児外科支援技術}

(1)術前診断

胎児診断では，主に超音波診断装置が用いられる。 最近では 3D 超音波診断装置を用いた診断が行われ， 胎盤・胎児の形態および機能的観察も可能となりつつ ある. また, カラードップラーを併用した胎児心疾患診断 も可能であり, 対象とする疾患のより詳細なデータベー スの構築を進めている.

(2)術中観察・ナビゲーション

双胎間輸血症候群では, 胎盤から $10 \mathrm{~mm}$ 前後までレ 一ザファイバを近づけて治療を行うが, 通常使用する 2D 内視鏡では距離感が掴みにくい. 術中胎盤損傷は 大量出血の原因となるため, 近接覚の把握は不可欠で ある. そこで, 新興光器製作所では, 胎児手術を対象と した細径の立体内視鏡を開発している.この立体内視 鏡は直径 $5.4 \mathrm{~mm}$ で先端に $1 / 10$ インチのマイクロ CCD を2 個搭載し, 27 万画素を実現している. 
また, 内視鏡や術具を, 胎盤や羊膜の損傷を避けな がらターゲットへと導くことを目的として, 超音波診断装 置を併用した術中ナビゲーション技術の開発も進めて いる.

(3)治療支援デバイス

子宮にあけた 3-4mm の切開口から挿入し, より高い 操作性を実現するための術具・デバイス開発を進めて いる. 日本原子力研究所・ペンタックス株式会社では, 治療用レーザファイバと観察用ファイバを一本に統合し た複合光ファイバの開発が進められている.これにより, ターゲットを視野中心に観察しながらレーザ焼灼を行う ことが可能となる.

また, 術具先端に高い自由度を持たせるための極細 径多自由度手術口ボッ鉗子の開発も進められている。 東京大学ではリンク駆動式 ${ }^{3)}$, 早稲田大学ではワイヤ駆 動式 ${ }^{4)}$ の極細径多自由度マニピュレータを開発しており, 双胎間輸血症候群のレーザ手術, 二分脊椎症胎児期 修復術への応用を考えている.いずれも内部が中空で あることから，上記の複合光ファイバを捜入することも検 討されている.

上記の，(1)術前診断，(2)術中観察・ナビゲーション， (3)治療支援デバイスの分野で開発された技術を統合 することで, 胎児手術支援の統合システムを開発してい $<$.

\section{4. まとめと今後の展望}

本報告では, 双胎間輸血症候群(TTTS) と二分春 椎症を対象とした手術支援デバイス開発を中心に述べ た. 今後は横隔膜へルニア, 胎児心疾患についても技 術開発が進むものと考える.

胎児外科を対象と寸る工学的支援には様々な制約 があり，技術開発には多くの困難を伴う.しかしながら， 胎児外科用に開発された技術を術中制約のより少ない 他分野一応用・展開していくことは比較的容易であり, 今回の開発技術の汎用化やコンピュータ外科の今後の 発展に大いに寄与すると期待する.

\section{謝辞}

本研究の一部は, 平成 17 年度厚生労働省身体機能 解析・補助・代替機器開発研究事業と成育医療研究委 託事業の支援を受けて行われている.

\section{文献}

1) T.Chiba, M.R.Harrison, C.T.Albanese and D.L.Farmer, "Fetal Surgery: Past, Present, and Future", Fetal Surgery Japan Society of Prenatal and Neonatal
Medicine,Vol.36,No.4, pp.524-539,2000

2) Enrico Danzer, Roman M. Sydorak, Michael R. Harrison, Craig T. Slbanese, "Review Minimal access fetal surgery", Europian Journal of Obstetrics and Gynecology and Reproductive Biology,Vol.108,3-13,2003

3) 山下紘正, 他:多節スライダ・リンク機構を用いた腹部外 科手術用鉗子マニピュレータの開発, 日本コンピュータ 外科学会誌, Vol. 5, No. 4, pp. 421-427, 2004

4) 原田香奈子, 坪内広太, 千葉敏雄, 藤江正克, Open-MRI下における低侵襲胎児手術用マニピュレータ の開発, 第 13 回日本コンピュータ外科学会論文集, pp.111-112， 2004 